\title{
Population trends of Northern Lapwing, Eurasian Curlew and Eurasian Oystercatcher over 15 years in a southwest Norwegian farmland
}

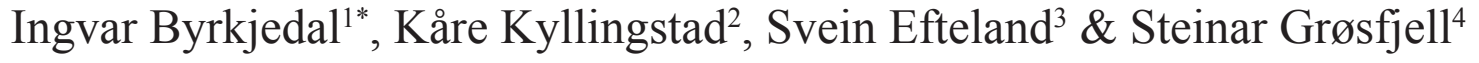 \\ ${ }^{1}$ University Museum of Bergen, University of Bergen, P.O. Box 7800, Allégt. 41, NO-5020 Bergen, Norway; ${ }^{2}$ Kvellurveien 52, \\ NO-4300 Sandnes, Norway; ${ }^{3}$ Toreskogvei 35, NO-4352 Kleppe, Norway; ${ }^{4}$ Hasselveien 6, NO-4370 Egersund, Norway; \\ * correspondence: ingvar.byrkjedal@zmb.uib.no
}

\begin{abstract}
Northern Lapwing Vanellus vanellus, Eurasian Curlew Numenius arquata, and Eurasian Oystercatcher Haematopus ostralegus were censused annually around 20 April, between 1997-2011, along a standardized route in Jæren, SW Norway. The area censused comprises 2972 ha, consisting of grassland, arable land, improved pasture, and heather moor. The area is intensively farmed, but has since long been a core area for breeding Lapwing and Curlew, and inland breeding of Oystercatchers has a history of several decades. Number of censused Lapwings along the route varied between years from 137 to 497, Curlews from 18 to 55 and Oystercatchers from 15 to 81 . Linear regressions showed a statistically significant decline in Lapwings over the whole census period, while significant negative linear trends were found in numbers of Curlews and Oystercatchers over the 10 and 8-9 last years, respectively. The negative trend of the latter two species seems to have stopped in more recent years. Estimated from the regressions Lapwing numbers have declined by $44 \%$ over the census period, and by $53 \%$ when estimated from counts of the number of males. Since the trend is found in a core area of the species, this is a worrying situation for the Lapwing as a breeding bird in this region of Norway. The decline of Lapwing and Oystercatcher was more pronounced in cropland than in pasture habitats, indicating an effect from agricultural activities.
\end{abstract}

Key words: Population declines, farmland waders, shorebirds, Vanellus vanellus, Numenius arquata, Haematopus ostralegus

\section{INTRODUCTION}

Over the recent decades many bird species breeding in farmland have been declining. Among these, Northern Lapwing Vanellus vanellus (hereafter Lapwing) and Eurasian Curlew Numenius arquata (hereafter Curlew) have shown unfavourable population trends over much of their European range (Delany et al. 2009, Vorisek 2004, 2005, BirdLife International 2011), after their colonization of farmland following deforestation and agricultural development through several centuries culminated in the mid 1900 (Hale 1980).

In Britain, Lapwing populations declined during the 1960s (Tucker et al. 1994), then stabilised until mid 1980s, when a new population decline started. Declines in Lapwing populations have later been found in a number of European countries, and in many places the declines seems to continue (Shrubb 2007, Hötker 2007, Delany et al. 2009, Petersen 2009).

Curlew populations in Europe have been declining since 1970 (Tucker et al. 1994, van Gils \& Wiersma 1996), with declines more pronounced in mid Europe (e.g. Łukasz \& Wylegała 2011). Declines also took place on more northern breeding grounds, but here this development seems to have reversed in recent years (Hötker 2007, Ottvall et al. 2008, Delany et al. 2009).

The recent decline in farmland birds is primarily attributed to man-made habitat changes from intensification in agriculture, drainage of wetter ground, afforestation, invasion of shrub, planting of windrows along fields (the latter two favouring spread of predators) and, in Lapwing and Curlew, also hunting has possibly contributed to population decreases (Petersen 2009, BirdLife International 2011).

From Norway little is known about the population trends of Lapwing and Curlew. The Norwegian Breeding Bird Atlas (Gjershaug et al. 1994) characterized these species as having shown a "slight decline" (20-50\% population reduction), while the Norwegian Red List categorises Lapwing and Curlew as near threatened (Kålås et al. 2010). However, published time series data from censuses have not been available.

Situated in the southwestern part of Norway, the region of Jæren is an important farmland district and belongs to the core areas of breeding Lapwings and Curlews in the country (Gjershaug et al. 1994). Given their current European decline, a census of population trends of these two species in a core area would be of 


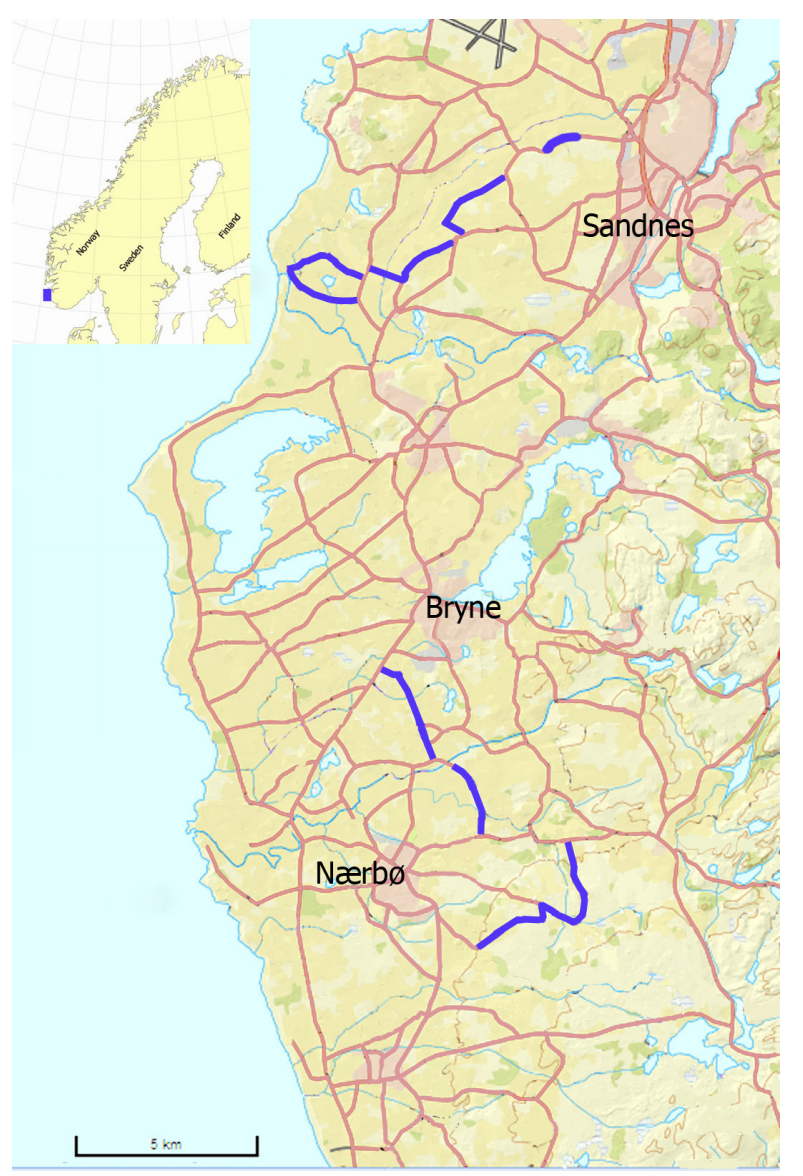

Figure 1. Road transects used for the standard annual censuses shown in blue; other main roads in red. Location of Jæren indicated by blue rectangle on inserted map.

particular interest.

In the region of Jæren Eurasian Oystercatchers Haematopus ostralegus (hereafter Oystercatcher), although primarily a bird of coastlines, have been breeding in farmland habitat over several decades (Carlsson 1988), a development worth monitoring, as population changes are likely to show up first in peripheral habitats.

We have performed annual counts of these three wader species in Jæren along a fixed route since 1997. The present paper shows the population trends obtained from the counts over 15 consecutive years including 2011 and relates the trends to habitats with high and low levels of agricultural activities.

\section{STUDY AREA AND METHODS}

Each year census was performed along $27 \mathrm{~km}$ of road, covering an area of 2972 ha (Figure 1). The route covered cultivated grassland (varying from 1480 to1869 ha over the 15 yr period), arable land (580-752 ha), improved pasture (increasing from 226-499 ha) and heather moor (decreasing from 217 to $53 \mathrm{ha}$ ). The counts were performed from a car making stops about every 50-100 m, during which the fields to both sides of the car were scanned with 8-10X binoculars, and 20-40X spotting scopes as needed. By not leaving the car we avoided disturbance and therefore were able to count birds in the fields that they occurred. Most fields were well defined by fences, but some were defined by other topographical features and these were marked on maps to ensure that the same areas were included each year. The birds were counted and recorded separately field by field. The distance to the farthest point on the perimeter perpendicular to the road for single fields was on average $430 \mathrm{~m}$ (range 75-1260; $\mathrm{n}=192$ ); in most fields, however, most of the perimeter was only 200-400 m away.

Annual censuses were performed over two days, on the Saturday, continuing on the Sunday, closest to 20 April. At this time of the season the three species are present on their breeding territories, either in prelaying, laying or early incubation phase, while the vegetation is still showing very little growth and the birds, even most of those incubating, are easily seen. Usually, the weather did not create any problems for visibility, except in 1998, 2004, 2007 and 2008, when mist or rain set in, causing us to complete the censuses over one extra day when the weather improved.

Because of their territorial defence activities, and because they incubate less, males are often more conspicuous than females. The number of males may be more equivalent to number of territories than are the total numbers. In Lapwing, total numbers might also be affected by varying degree of polygyny (Byrkjedal et al. 1997, Parish et al. 1997). We therefore attempted to sex the birds. This was usually obtained with Lapwings (males having more contrasting plumage and longer crests) and Curlew (males having noticeably shorter bills than females), but not with Oystercatcher. For Lapwings and Curlews that could not be sexed (median $8 \%$ per year [range $1-21 \%$ ] of the Lapwings and median $11 \%$ [range $0-39 \%$ ] of the Curlews) the number of males were estimated from the proportions of males in the sexed portion for that year.

While Oystercatchers were impossible to sex in the field, we estimated number of pairs from the distribution of individuals. Two birds a few metres apart were considered a pair, as were two birds seen in the same field, when there were no other oystercatchers in neighbouring fields. Also a single bird in a similar situation was considered to represent one pair. Single birds in each of two neighbouring fields were considered as one pair, whereas three birds in one field were considered two pairs. More than three oystercatchers near each other in one field was considered a feeding flock and not used in the estimation of pairs, unless the birds were distributed in a "pairwise" fashion.

During each yearly census, habitat in each field was classified as grass, tilled, stubble, improved pasture (originally heather moor, fertilized to become 

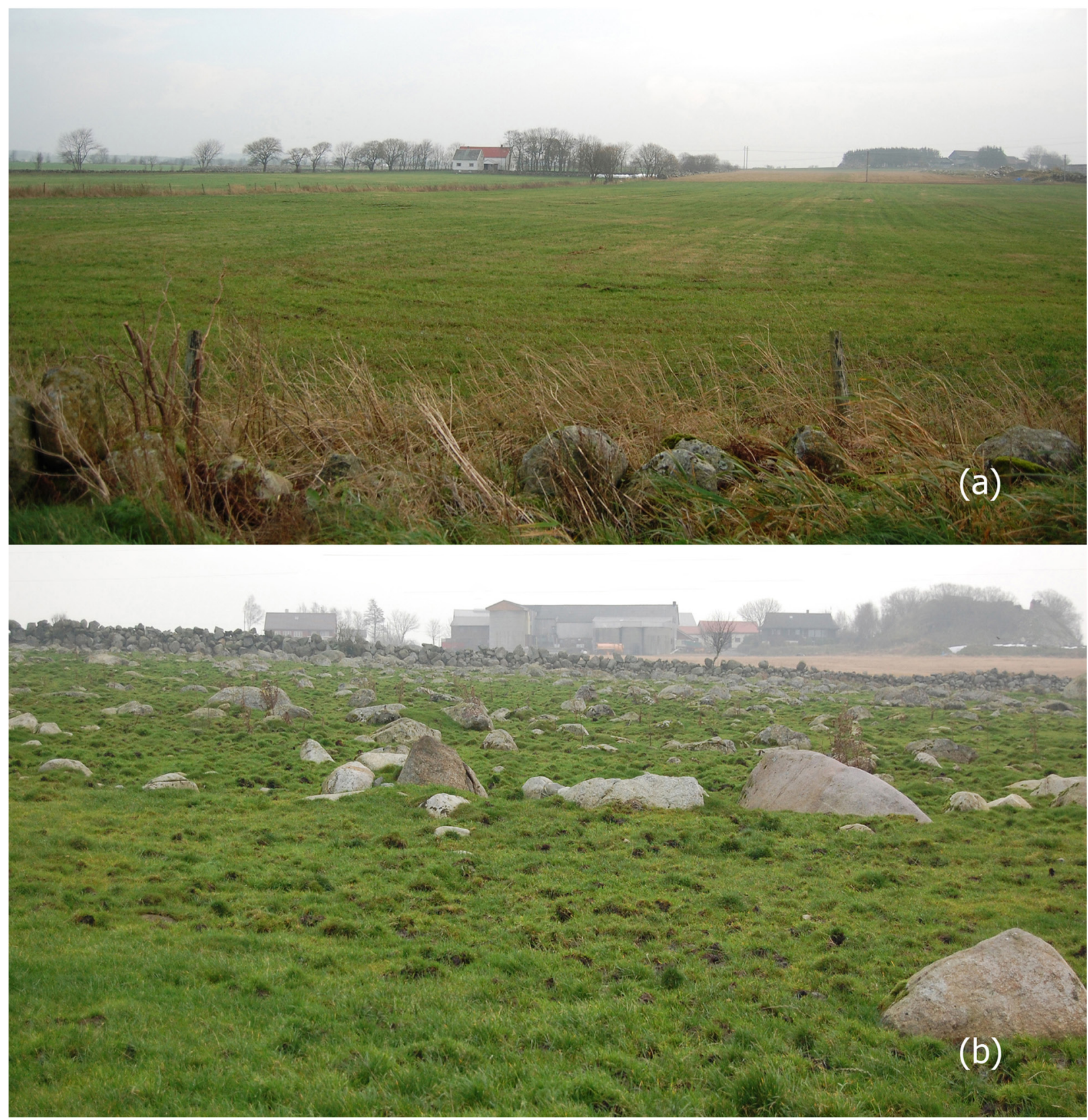

Figure 2. Uniform grass field (a) and improved pasture (b) from the census route.

grass-dominated pasture), heather moor, and other habitat (including horse paddocks, fields turned into construction areas since previous census, etc.). The final use each year of fields appearing as grass fields, tilled and stubble field at the time of census was not followed, but these habitats were nevertheless repeatedly subject to machinery treatment during the summer season, and we pooled these as cropland. Fertilized grazing and moorland were lumped as pastures, characterized by low or no machinery treatment in the summer season. The category "other habitats" constituted a negligible portion (0-1.4\%), and held no birds; these were disregarded. Habitat was thus considered in two broad categories: cropland and pasture (Figure 2), and the use of these by the birds was compared with available areas for each year (except 1999 when data on habitat were not recorded, and in 1998 for Curlew with too few individuals sexed). Habitat relations are presented for males (Lapwing, Curlew) and birds judged to be pairs (Oystercatcher), to avoid pseudoreplication from use of total individuals censused.

Using SPSS 19.0, we chose linear regressions to estimate numerical trends. Separate regression analyses were performed over cumulative number of years, counting backwards starting with the regression for the last four years (2008-2011). For simple linear regressions the standardized regression coefficients (Beta) correspond to the values of Pearson correlation 
coefficients (r), and their critical values follow the same distribution. The coefficients were compared graphically to critical values of $r$, extracted from Zar (2010) and plotted against the number of years backwards from 2011, with values below the critical line indicating time-periods over which significant declines occurred.

Similarities in annual variation might indicate whether the species are subject to the same factors acting on their populations. Thus, we performed Pearson correlations between all combinations of species total annual numbers as well as for males. To look for preferences of cropland versus pasture, observed and expected values of habitat use were compared by Wilcoxon Paired Tests. Two-tailed probabilities were used throughout.

\section{RESULTS}

In spite of a population peak in 2001, Lapwings showed a statistically significant decline over the 15 year period for total numbers as well as for estimated number of males (Figure 3; linear regressions and test parameters are given in the Figure caption). From the linear regression the total numbers of Lapwings were estimated to have decreased from 447 in 1997 to 249 in 2011, i.e., by $44 \%$. Using only the data on males gives a change from 267 males to 125 , a decline of $53 \%$. For the full 15 years census period no statistically significant trends were found for Curlew (Figure 4) and Oystercatcher (Figure 5), and male Curlews only showed a significant negative trend over the last 10 years, but none of the regression coefficients over shorter or longer time periods were significant (Figure 4). For Oystercatcher, there was a statistically significant decline over the last 8-9 years, and over a shorter time scale many of the coefficient values approached significance suggesting that declines have continued (Figure 5).

Lapwing numbers (total as well as males) did not correlate with the numbers of Curlews (total and males) and Oystercatcher (totals and pairs), but the latter two species showed a significant correlation in numbers (Table 1).

Of the two habitat categories, cropland and pasture, cropland constituted $81.7 \%$ (median) of the area at the time of censuses ( 1 and 3 quartiles: $81.1 \%$ and 82.4 $\%$ ). $84.3,80.0$ and $89.9 \%$ of the Lapwing males ( 1 and 3 quartiles: $82.3 \%$ and $89.4 \%$ ), Curlew males ( 1 and 3 quartiles: $69.6 \%$ and $89.5 \%$ ), and Oystercatcher pairs (1 and 3 quartiles: $81.9 \%$ and 93.7\%) were observed in cropland, respectively. Wilcoxon Paired Tests performed on observed vs. calculated expected numbers showed Lapwing males to be statistically significantly overrepresented on cropland $(Z=2.665, p=0.008, n=14$ years), while the distribution of Curlew males and Oystercatcher pairs did not differ from random (Curlew:

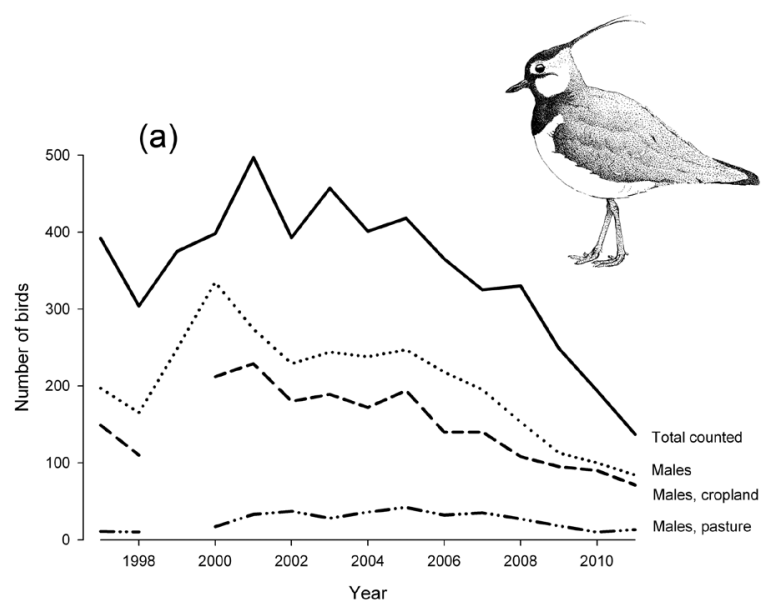

(b)

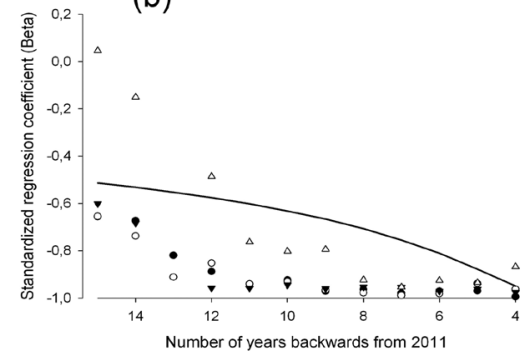

Figure 3. (a) Number of Lapwings censused 1997-2011. For some of the years number of males among unsexed birds has been estimated from the proportion of males among the sexed birds (see text); this does not apply to data related to habitat. Linear regressions for the whole period: total, $y=-14,136 x$ $+28676,921, \mathrm{~F}=9,811, \mathrm{p}=0,008$; males, $\mathrm{y}=-10,146 \mathrm{x}+$ $20528,952, \mathrm{~F}=9,767, \mathrm{p}=0,008$; males cropland $\mathrm{y}=-6.68 \mathrm{x}$ $+13537.83, \mathrm{~F}=6.771, \mathrm{p}=0.023$; males pasture, $\mathrm{y}=0.116 \mathrm{x}$ $-207.452, F=0.024, p=0.879$. Habitat data for 1999 missing. (b) Standardized regression coefficients over cumulative year spans, starting with the four years backwards from 2011. Line shows critical values for $p=0.05$. Filled circles $=$ total number of birds; open circles $=$ males; filled triangles $=$ males in crop fields; open triangles $=$ males in pasture fields.

$\mathrm{Z}=1.572, \mathrm{p}=0.12, \mathrm{n}=13$ years; Oystercatcher: $\mathrm{Z}=1.852$, $\mathrm{p}=0.06, \mathrm{n}=14$ years), yet Oystercatcher pairs were close to being overrepresented on cropland. When the population trends are considered separately by habitat categories over the whole 15 year period, Lapwing males showed a statistically significant decline in cropland but not in pasture (Figure 3). A negative trend, however, was found also for males in pastures during the 11 years or less from 2011, except for the last four years. In Curlew (Figure 4) no significant trends were found for males in either of the two habitat categories, while in Oystercatcher (Figure 5) a decline in the number of pairs occurred in cropland over the eight and nine years from 2011. For time spans less than that, the 

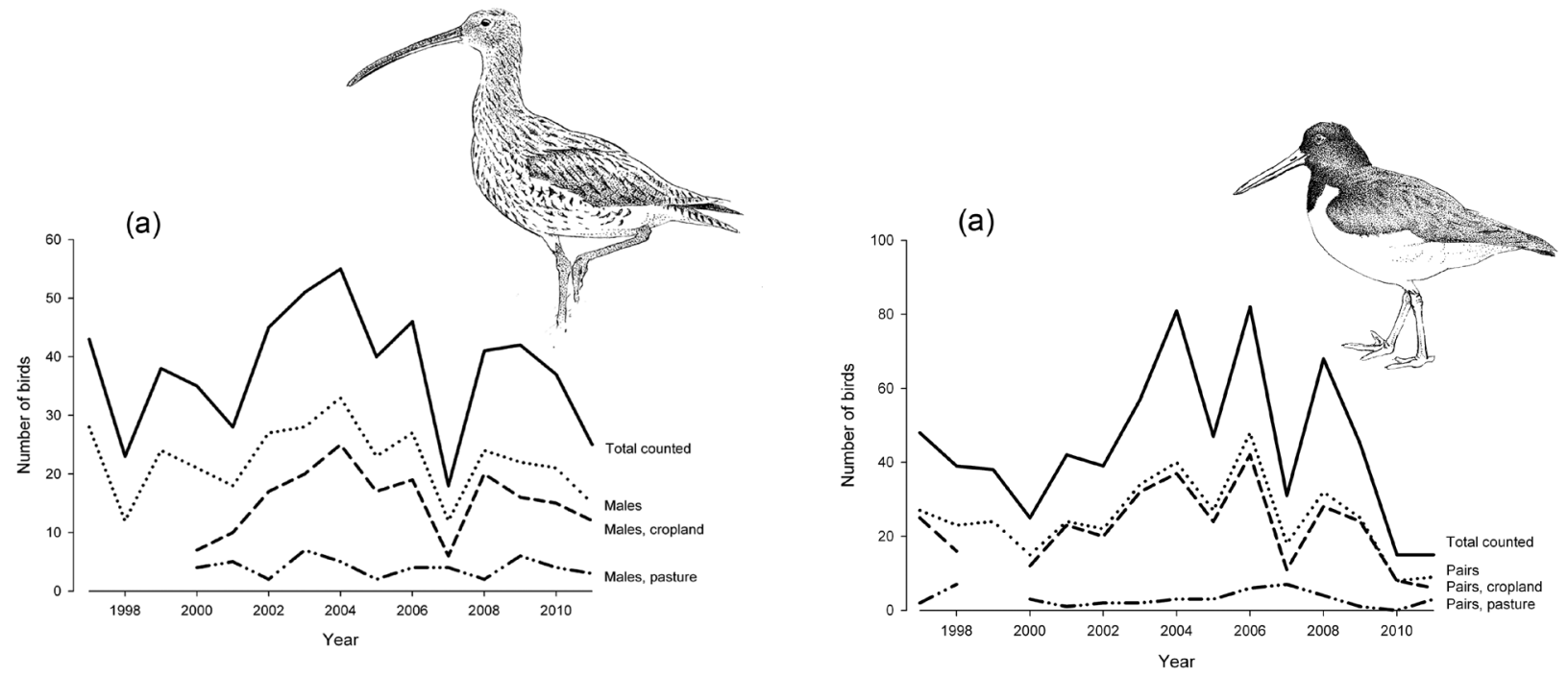

(b)

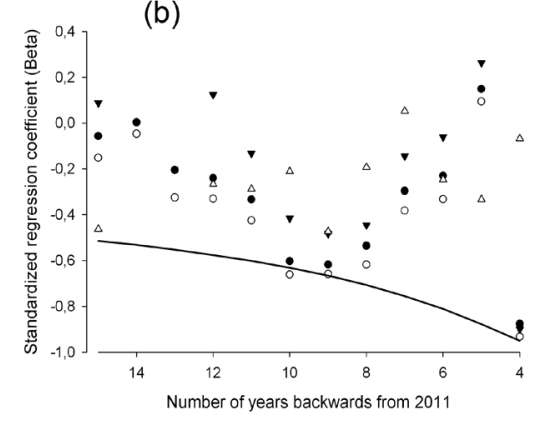

(b)

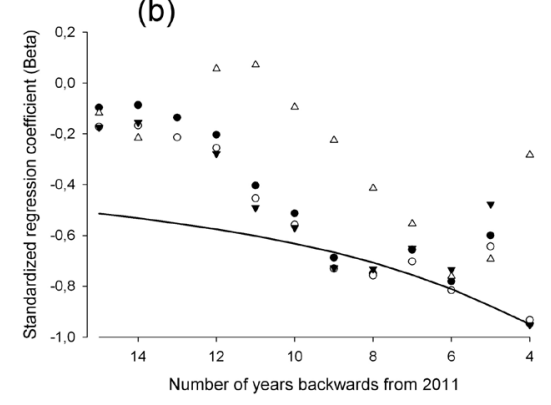

Figure 4. (a) Number of Curlews censused 1997-2011. For some of the years number of males among unsexed birds has been estimated from the proportion of males among the sexed birds, (see text); this does not apply to data related to habitat. Linear regressions for the whole period: total, $\mathrm{y}=-0.132 \mathrm{x}+$ $302.614, \mathrm{~F}=0.042, \mathrm{p}=0.841$; males, $\mathrm{y}=-0.4 \mathrm{x}+823.333, \mathrm{~F}$ $=1.018, \mathrm{p}=0.331 ;$ males cropland, $\mathrm{y}=0.066 \mathrm{x}-116.262, \mathrm{~F}$ $=0.028, \mathrm{p}=0.870 ;$ males pasture, $\mathrm{y}=-0.155 \mathrm{x}+315.328, \mathrm{~F}$ $=1.777, \mathrm{p}=0.209$. Habitat data for 1998 and 1999 missing. (b) Standardized regression coefficients over cumulative year spans, starting with the four years backwards from 2011. Line shows critical values for $p=0.05$. Filled circles $=$ total number of birds; open circles = males; filled triangles $=$ males in crop fields; open triangles $=$ males in pasture fields.

statistical significance is lost, except for the last four years $(\mathrm{F}=19.322, \mathrm{p}=0.048)$. No significant trend was found for Oystercatcher pairs in pasture.

\section{DISCUSSION}

The study shows that Lapwing numbers have declined markedly in Jæren over the 15 years from 1997 to 2011. These data indicate the population roughly to have halved in this important breeding area. A similar population development is not evident for Curlews and farmlandbreeding Oystercatchers. Although a negative trend is seen over the 8-10 last years, the decrease in these two

Figure 5. (a) Number of Oystercatchers censused 1997-2011. Criteria for observations judged to be pairs, see text. Linear regressions for the whole period: total, $\mathrm{y}=-0,446 \mathrm{x}+939,443$, $\mathrm{F}=0,125, \mathrm{p}=0,730$; pairs, $\mathrm{y}=-0,414 \mathrm{x}+855,295, \mathrm{~F}=0,402$, $\mathrm{p}=0,537$; pairs, cropland, $\mathrm{y}=-0.423 \mathrm{x}+868.975, \mathrm{~F}=0.375$, $\mathrm{p}=0.552$; pairs, pasture, $\mathrm{y}=-0.058 \mathrm{x}+119.616, \mathrm{~F}=0.169, \mathrm{p}$ $=0.681$. Habitat data for 1999 missing.

(b) Standardized regression coefficients over cumulative year spans, starting with the four years backwards from 2011. Line shows critical values for $p=0.05$. Filled circles $=$ total number of birds; open circles $=$ pairs; filled triangles $=$ pairs in crop fields; open triangles $=$ pairs in pasture fields.

species seems to have stopped in more recent years.

The censuses probably give a reliable picture of the trends in numbers along the route, as the method has been standardized in relation to date, area covered, observation technique employed, and personnel involved. Moreover, all three are large species that are relatively easy to observe in the flat uniform fields making up more than $80 \%$ of the area censused. All three species are dispersed on territories and incubate over a time span of several weeks, and the censuses, performed about 20 April, took place in the incubation period of Lapwings and Curlews in the area, and in the pre-laying territorial period of Oystercatchers (personal observations). The area covered is large enough to be 
Table 1. Correlations in numbers among Lapwings, Curlews, and Oystercatchers over the 15 year period.

\begin{tabular}{lrr}
\hline Species pair & $\mathrm{r}$ & $\mathrm{p}$ \\
\hline Lapwing total numbers vs. Curlew total numbers & 0.36 & 0.189 \\
Lapwing total numbers vs. Oystercatcher total numbers & 0.48 & 0.069 \\
Curlew total numbers vs. Oystercatcher total numbers & 0.66 & 0.007 \\
Lapwing males vs. Curlew males & 0.31 & 0.264 \\
Lapwing males vs. Oystercatcher pairs & 0.31 & 0.257 \\
Curlew males vs. Oystercatcher pairs & 0.64 & 0.011 \\
\hline
\end{tabular}

representative of the wider Jæren farmland. The number of Lapwings, up to 500 birds, should be sufficient to capture population trends. During the last two decades bird-watchers (personal communications) in the region have noted Lapwings disappearing as a breeding bird in peripheral areas around Jæren. The area censused by us belongs to a core area for Lapwings in SW Norway, and in such an area it may take longer for a population decline to show up than in the less optimal areas. The fact that such a long-term and marked trend is found in our core-area census material indicates that the population situation for Lapwings in WS Norway could be severe.

The numbers of Curlews and Oystercatchers are much lower than those of Lapwings, and therefore far more affected by stochastic factors and census efficiency. Yet, the difference between the Lapwing and the latter two species in population trends may be real; differences in habitat preferences on the breeding grounds as well as in winter may be involved.

In contrast to the other two species, Lapwings in the present study are overrepresented in cropland in relation to available cropland area, and it is in cropland their decline is chiefly found, indicating that Lapwings, not unexpectedly, are negatively affected by the farming activities in the region. In the later part of the census period the decline apparently also has spread to birds breeding in pastures. Oystercatcher too shows a decline in cropland over some of the years, but this trend may have been broken over the later years. However, the ability to detect population changes diminishes in small number of years.

Curlews and Oystercatchers, although often found in cropland, hold larger territories than Lapwings and are more prone to extraterritorial feeding (Cramp \& Simmons 1983); they might thus nest in pastures and still feed (and become recorded by us) in neighbouring crop-fields. The much smaller Lapwing territories, on the other hand, are likely to be wholly situated in the habitat in which the birds are recorded, and thus more subject to activities taking place there, such as intensive farming operations in cropland habitats. A majority of the cropland fields in the area are grass fields for production of silage. Many spring-sown fields are subject to ploughing and harrowing during the census period, i.e., while most Lapwings are incubating. With their slightly later breeding phenology Curlews and Oystercatchers might, to a larger extent than Lapwings, escape early ploughing. Lapwings readily lay replacement clutches (Cramp \& Simmons 1983, Shrubb 2007), but the success of replacement clutches will depend largely on the time window until crop harvesting, and presumably also on the way fertilizer is applied to the fields. Autumn sowing of perennial grasses in order to achieve harvesting three or four times annually has become more common over the later years, with a first harvest already in May (e.g., Sandvik \& Arnstein 2009) at a time when a majority of the Lapwing broods are still not fledged (cf. Larsen et al. 2003 ). Increased efforts to drain cropland may affect lumbricid activities (Edwards \& Lofty 1993) and thus the availability of the birds' most important food source (Cramp \& Simmons 1983, Shrubb 2007, own obs.), and increased planting of windrows along cropland fields may attract avian as well as mammalian nest predators (Berg et al. 1992).

South-west Norwegian populations of all three species winter in the North Sea countries, and in particular in the British Isles (Bakken et al. 2003). While Lapwings to a large extent winter in terrestrial habitats, especially farmland, Curlews and Oystercatchers are more prone to winter on marine mudflats and estuaries (Cramp \& Simmons 1983). Different developments of these habitats might cause winter mortality to differ between the species.

The exact cause for the population trends observed in the present study remains speculative. However, given the different trends between habitats declines most likely have something to do with the agricultural use of the fields. Studies of the birds' reproductive success in the area, especially of Lapwing, would be needed to get an insight into the causes of the population decline.

Acknowledgements. We are most grateful to Adriaan de Jong and Jennifer Smart for valuable comments on the manuscript.

Sammendrag. Bestandsutvikling hos vipe, storspove og tjeld på Jæren i 15-årsperioden 1997-2011. Vipe, storspove og tjeld ble talt årlig langs en fastlagt rute over Jæren i årene 1997-2011. Tellingen ble lagt til rundt 20. april hvert år. På 
denne tiden ligger vipe og storspove på reir og tjelden er $\mathrm{i}$ preleggingsfase på territoriene. I alt 2972 ha ble dekket av tellingene, og omfattet grasmark for siloproduksjon, åkermark, kulturbeite og lynghei. Vipetallene varierte mellom 137 og 497 individer, storspove mellom 18 og 55 individer og tjeld mellom 15 og 81 individer. Vipene viste en klar nedgang i antall over 15-årsperioden, med 44 \% nedgang beregnet fra lineær regresjon basert på totaltallene og hele $53 \%$ nedgang om tallene for hanner ble lagt til grunn. En oppdeling av analysen i to habitatkategorier, dyrka mark og utmark, viste at vipenedgangen hovedsakelig var knyttet til forekomst på dyrka mark, men en viss nedgang også på beitemark kunne spores over de senere 11 årene. Noen bestemt trend kunne ikke oppdages i tallene for storspove og tjeld når hele 15-årsperioden ble lagt til grunn, men en nedgang lot seg fastslå for storspove over de siste 10 årene og for tjeld over de siste 8-9 årene og som for vipe viste tjelden en nedgang på dyrket mark over deler av telleperioden. Nedgangen ser senere ut til å ha stoppet for disse to artene. Den store nedgangen i vipe tyder stekt på kritiske forhold for bestanden i denne delen av landet. Årsaken til nedgangen kan ikke fastslås, men materialet antyder at jordbruksaktivitetene i området ikke uventet spiller en rolle.

\section{REFERENCES}

Bakken, V., Runde, O. \& Tjørve, E. 2003. Norsk ringmerkingsatlas. Vol. 1. Stavanger Museum, Stavanger.

Berg, Å., Lindberg, T. \& Källebrink, K.-G. 1992. Hatching success of Lapwings on farmland: differences between habitats and colonies of different sizes. J. Anim. Ecol. 61: 469-476.

BirdLife International. 2011. IUCN Red List for birds. Downloaded from http://www.birdlife.org on 04/07/2011.

Byrkjedal, I., Grønstøl, G.B., Lislevand, T., Pedersen, K. M., Sandvik, H. \& Stalheim, S. 1997: Mating system and territory in Lapwings Vanellus vanellus. Ibis 139: 129137.

Cramp, S. \& Simmons, K.E.L. 1983. The birds of the Western Palearctic, Vol. 3. Oxford University Press, Oxford.

Delany, S. Scott, D., Dodman, T. \& Stroud, D. (eds.). 2009. An atlas of wader populations in Africa and western Eurasia. Wetlands International, Wageningen.

Edwards, C.A. \& Lofty, J.R. 1993. Biology of earthworms. Chapman \& Hall, London.

Hale, W.G. 1980. Waders. Collins, London.

Hötker, H. 2007. Entwicklung der Brutbestände der Wiesen-
Limikolen in Deutschland - Ergebnisse eines neuen Ansatzes im Monitoring mittelhäufider Brutvogelarten. Vogelwelt 128: 49-65.

Kålås, J.A., Gjershaug, J.O., Husby, M., Lifjeld, J., Lislevand, T., Strann, K.-B. \& Strøm, H. 2010. Aves. pp 419-429 in Kålås, J.A., Viken, Å., Henriksen, A. \& Skjelseth, S. (eds.). The 2010 Norwegian Red List for species. Artsdatabanken, Trondheim.

Larsen, V.A., Lislevand, T. \& Byrkjedal, I. 2003. Is clutch size limited by incubation ability in Northern Lapwings? J. Animal Ecology. 72: 784-792.

Łukasz, Ł. \& Wylegała, P. 2011. Recent data on the declining breeding population of European Curlew Numenius arquata in western Poland. Wader Study Group Bull. 118: 14-17.

Ottvall, R., Edenius, L., Elmberg, J., Engström, H., Green, M., Holmqvist, N., Lindström, A., Tjernberg, M. \& Pärt, T. 2008. Populationstrender för fågelarter som häckar i Sverige. Naturvårdsverket, rapport 5813. Electronic Publication (http://www.naturvardsverket.se/Documents/ publikationer/620-5813-5.pdf)

Parish, D.M.B., Thompson, P.S. \& Coulson, J.C. 1997: Mating systems in the Lapwing Vanellus vanellus. Ibis 139: 138-143.

Petersen, B.S. 2009. European Union management plan 2009-2011: Lapwing Vanellus vanellus. Natura 2000, Technical Report 2009-033.

Sandvik, A. \& Arnstein, A. 2009. Hykor raisvingel - sikker treslåttseng. Vestlandsk Landbruk 6(09): 4-5.

Shrubb, M. 2007. The Lapwing. T. \& A.D. Poyser, London.

Stroud, D.A. \& Reed, T.A. 1986. The effect of plantation proximity on moorland breeding waders. Wader Study Group Bull. 46: 25-28.

Tucker, G.M., Heath, M., Tomialoc, L. \& Grimmett, R.F.A. 1994. The ecology and conservation of Lapwings Vanellus vanellus. UK Nature Conservation 9.

Vorisek, P. 2004. Population trends of European common birds 2003. Pan-European Common Bird Monitoring. Internet publication, http://www.birdlife.cz/wpimages/ other/ETrends(2)2003.pdf.

Vorisek, P. 2005. Population trends of European common birds, 2005 update. Internet publication, European Bird Census Council: http://www.ebcc.info.

Zar, J.H. 2010. Biostatistical analysis. Pearson Prentice Hall. Upper Saddle River, NJ.

Received 20 December 2011. Accepted 15 February 2012 